\title{
DUKUNGAN STRATEGIS DAN OPERASIONAL PEMERINTAH DALAM PEMENUHAN HAK KESEHATAN ANAK TUNAGRAHITA DI KOTA SURABAYA
}

\author{
Government's Strategic and Operational Support to Fulfill the Health Right of \\ Children with Mental IIIness in Surabaya
}

\author{
Ana Riskhatul Fitria \\ PP PERSAKMI, Indonesia \\ E-mail: ana.riskhatul.fitria-2014@fkm.unair.ac.id
}

\begin{abstract}
Background: Social justice is a condition of fulfilling material, spiritual and social needs of citizens to live properly and to develop themselves in carrying out the social functions. The social welfare rate in Indonesia was still low amounted to 62.8 in 2016. Children with mental illness problems experience social welfare. The government has provided support both strategic support and operational support for their lives.

Aim: The objective of the research is to analyze the government's support for fulfilling child's health rights for those who suffer from mental illness.

Method: This research was descriptive. The data were collected by using policy review and observation. Policy review was used to discover the strategic support given by government to fulfill health needs of mentally illed children. Meanwhile, the observation was to find out government's operational support for Kalijudan Surabaya Technical Implementation Unit (UPT) in Basic Social Services.

Results: The results show that there is a good strategic support for the children with mental illness. The operational support has been implemented, but not in accordance with the existing regulations. However, Kalijudan Surabaya Technical Implementation Unit (UPT) in Basic Social Services has provided the right of health by cooperating with related parties.

Conclusion: It can be concluded that the strategic support given includes Law Number 8 Year 2016 about disabled people, Health Ministry Law Number 25 Year 2014 about child's health support, and Surabaya Mayor's Law Number 2 Year 2013 about organization of Kalijudan Surabaya Technical Implementation Unit (UPT) at Basic Social Service Department. The Kalijudan Surabaya Technical Implementation Unit (UPT) in Basic Social Services had also given operational supports for mentally illed chidren's health needs.
\end{abstract}

Keywords: children with mental illness, health right, regulation

\begin{abstract}
ABSTRAK
Latar Belakang: Keadilan sosial adalah kondisi terpenuhinya kebutuhan material, spiritual dan sosial warga negara agar dapat hidup layak dan mampu mengembangkan diri, sehingga dapat melaksanakan fungsi sosialnya. Angka kesejahteraan sosial di Indonesia masih rendah yaitu di angka 62,8 pada tahun 2016. Salah satu kelompok yang mengalami masalah kesejahteraan sosial adalah kelompok anak tunagrahita. Pemerintah telah memberikan dukungan baik dukungan strategis maupun dukungan operasional demi berlangsungnya kehidupan mereka.

Tujuan: Tujuan dari penelitian ini adalah untuk mengetahui dukungan pemerintah dalam pemenuhan hak kesehatan anak tunagrahita. Jenis penelitian ini adalah deskriptif.

Metode: Teknik pengumpulan data dilakukan melalui telaah kebijakan dan observasi. Telaah kebijakan digunakan untuk mengidentifikasi rencana strategis yang diberikan oleh pemerintah untuk memenuhi hak kesehatan anak tunagrahita. Sedangkan, observasi digunakan untuk mengetahui dukungan operasional pemerintah di UPTD Pondok Sosial Kalijudan Kota Surabaya.

Hasil: Hasilnya menunjukkan bahwa sudah terdapat dukungan strategis untuk anak tunagrahita. Sedangkan dukungan operasional yang dilaksanakan di UPTD Ponsos Kalijudan masih belum sesuai dengan peraturan. Namun UPTD Ponsos Kalijudan Surabaya sudah memberikan pemenuhan hak kesehatan dengan baik dengan melakukan kerja sama dengan pihak yang terkait.

Kesimpulan: Dukungan strategis yang diberikan termasuk UU RI No 8 Tahun 2016 tentang penyandang disabilitas, Peraturan Menteri Kesehatan RI No 25 Tahun 2014 tentang upaya kesehatan anak, dan Peraturan Walikota Surabaya No 2 Tahun 2013 tentang Organisasi Pondok Sosial Kalijudan pada Dinas Sosial Kota Surabaya. UPTD Ponsos Kalijudan telah memberikan dukungan operasioanl bagi kesehatan anak tunagrahita.
\end{abstract}

Kata Kunci: anak tunagrahita, hak kesehatan, peraturan 


\section{PENDAHULUAN}

Penyandang Masalah Kesejahteraan Sosial (PMKS) adalah seseorang, keluarga atau kelompok masyarakat yang karena suatu hambatan, kesulitan atau gangguan tidak dapat melaksanakan fungsi sosialnya sehingga tidak dapat terpenuhi kebutuhan hidupnya baik jasmani, rohani, dan sosial secara memadai dan wajar. Jenis Penyandang Masalah Kesejahteraan Sosial (PMKS) dikelompokkan menjadi anak, wanita, lanjut usia, penyandang cacat, tuna susila, keluarga, dan masyarakat (Putri, 2015).

Salah satu kelompok PMKS adalah anak, yang terdiri dari anak balita telantar, anak terlantar, anak yang menjadi korban tindak kekerasan atau diperlakukan salah, anak nakal, anak putus sekolah, dan anak cacat. Sebutan anak diberikan kepada siapapun yang berusia 0 sampai 18 tahun.Terdapat kelompok anak yang memiliki kemampuan intelektual di bawah rata-rata yang disebut dengan anak tunagrahita. Kelompok anak ini mempunyai keterbatasan intelegensi, sosial, dan fungsi mental sehingga mereka sulit menyesuaikan diri dengan lingkungannya. Penyebab seorang anak mengalami tunagrahita diantaranya karena faktor genetik, infeksi pada masa kehamilan, kelainan saat persalinan, dan kekurangan nutrisi saat lahir (Meria, 2015).

Menurut Peraturan Pemerintah Nomor 72 Tahun 1991, tunagrahita diklasifikasikan menjadi dua yaitu tunagrahita ringan dan tunagrahita sedang. Tunagrahita ringan masih mempunyai kemampuan di bidang akademik dan penyesaian sosial. Sedangkan tunagrahita sedang, membutuhkan bantuan untuk mencapai tujuannya. Ciri-ciri yang membedakan kelompok anak tunagrahita adalah perkembangannya tertinggal dibanding teman sebayanya, cara hidupnya tidak bervariasi, mudah bosan, kemampuan komunikasi terbatas, motivasi belajar rendah, dan tidak memiliki kepedulian terhadap lingkungan sekitarnya.

Anak tunagrahita mengalami kesulitan dalam berinteraksi sosial. Kesulitan ini dipengaruhi oleh beberapa faktor seperti faktor intelegensi itu sendiri dan faktor lingkungan. Interaksi sosial merupakan hal yang sangat penting bagi kehidupan seseorang. Interaksi sosial menjadi pedoman kehidupan bersama orang lain (Awalia, 2016).

Berdasarkan ciri-ciri yang telah disebutkan maka dibutuhkan penanganan khusus yang harus dilakukan untuk membantu anak tunagrahita dalam menjalankan kehudupannya. Beberapa cara yang dapat dilakukan untuk menangani anak berkebutuhan khusus atau anak tunagrahita adalah peran orang tua yang sangat penting yaitu mereka harus memiliki pemikiran yang terbuka; orang tua harus memiliki perhatian lebih dan pengawasan ekstra sejak dini; memberikan motivasi, perhatian, dan bimbingan; beradaptasi dengan anak; pendekatan emosional, mengembangkan keterampilan anak; mengajarkan tentang kemandirian; kerja sama orang tua dengan pihak sekolah; mengenalkan tentang norma, penghargaan, dan sanksi; memahami kebutuhan dan kebiasaan anak; serta memberikan terapi yang sesuai dengan kebutuhan anak (Shabrina, 2017).

Pada umumnya orang tua yang memiliki anak dengan kebutuhan khusus cenderung tertutup.
Mereka merasa bahwa orang lain akan memiliki stigma yang jelek kepada anak mereka. Sehingga orang tua seperti ini memilih untuk menyembunyikan anaknya. Terlebih untuk keluarga yang tidak mampu, mereka akan melakukan hal apapun untuk terlepas dari anak dengan kebutuhan khusus. Tidak jarang orang tua seperti ini meninggalkan anaknya di pinggir jalan. Hal seperti inilah yang dapat menambah jumlah penyandang masalah kesejahteraan sosial (Pawiono, Latri and Rosmaharani, 2016).

Di kota-kota besar seperti Kota Surabaya, angka kesejahteraan sosial masih rendah khususnya angka kesejahteraan anak. Di Surabaya tercatat 19 anak balita terlantar, 1.059 anak terlantar, 810 anak dengan disabilitas, dan 50 anak jalanan(Badan Pusat Statistik Provinsi Jawa Timur, 2016).

Penyebab rendahnya kesejahteraan sosial adalah pertumbuhan pembangunan di Kota Surabaya cukup cepat sehingga memicu terjadinya urbanisasi. Selain itu kemampuan Kota Surabaya untuk menyediakan fasilitas publik untuk para urban masih terbatas. Oleh sebab itu para urban melakukan pengembangan ekonomi non-formal secara bebas. Mereka membuat tempat tinggal di wilayah terlarang, melakukan pekerjaan seadanya yang termasuk kelompok PMKS seperti pengemis, gelandangan, bahkan WTS.

Untuk mengatasi hal tersebut Walikota Surabaya membentuk Unit Pelaksana Teknis Dinas (UPTD). UPTD merupakan unit yang dibentuk untuk melaksanakan kegiatan teknis operasional atau kegiatan teknis penunjang tertentu. Pemerintah Kota Surabaya memiliki lima UPTD dibawah Dinas Sosial Kota Surabaya. Kelima UPTD tersebut adalah UPTD Liponsos Keputih, UPTD Ponsos Kalijudan, UPTD Kampung Anak Negeri, UPTD Babat Jerawat, dan UPTD Griya Wredha.

Salah satu UPTD dibawah Dinas Sosial adalah UPTD Pondok Sosial Kalijudan. UPTD Ponsos Kalijudan merupakan UPTD yang menampung anakanak dengan kebutuhan khusus atau anak tunagrahita dan memberikan pembinaan. Penjangkauan anak tunagrahita di UPTD Ponsos Kalijudan adalah melalui razia, rujukan dari UPTD lain, Pemda/Pemkot, dan Dispendik. Untuk melakukan penjangkauan anak tunagrahita tersebut UPTD Ponsos Kalijudan bekerja sama dengan Polisi, Satpol PP, Bakesbang Linmas, Dinas Sosial, dan Kecamatan.

Anak tunagrahita yang dirawat di UPTD Ponsos Kalijudan mendapatkan pelayanan meliputi pelayanan pemenuhan kebutuhan jasmani, pemenuhan kebutuhan spiritual, dan pelayanan kesehatan. Selain itu anak tunagrahita tersebut mendapatkan bimbingan berupa bimbingan fisik, mental, sosial, dan keterampilan.

Tujuan penelitian ini adalah untuk mengetahui dukungan pemerintah dalam pemenuhan hak kesehatan anak tunagrahita, baik dukungan strategis maupun dukungan operasional.

\section{METODE}

Penelitian ini menggunakan metode deskriptif. Lokasi pengumpulan data dilaksanakan di Unit Pelaksana Teknis Dinas Pondok Sosial Kalijudan 
Kota Surabaya. Teknik pengumpulan data dilakukan dengan telaah kebijakan dan observasi. Telaah kebijakan dilakukan untuk mengetahui dukungan strategis yang diberikan oleh pemerintah untuk pemenuhan hak kesehatan anak tunagrahita. Metode telaah kebijakan adalah deskriptif. Kebijakan yang ditelaah meliputi Undang-Undang Republik Indonesia Nomor 8 Tahun 2016 tentang Penyandang Disabilitas, Peraturan Menteri Kesehatan Republik Indonesia Nomor 25 Tahun 2014 tentang Upaya Kesehatan Anak, dan Peraturan Walikota Surabata Nomor 2 Tahun 2013 tentang Organisasi Unit Pelaksana Teknis Dinas Pondok Sosial Kalijudan pada Dinas Sosial Kota Surabaya. Sedangkan observasi dilakukan untuk mengetahui dukungan operasional yang dilakukan di UPTD Pondok Sosial Kalijudan Kota Surabaya.

\section{HASIL DAN PEMBAHASAN}

\section{Dukungan Strategis}

Dukungan adalah segala bentuk bantuan yang diberikan kepada orang lain dalam menjalani kehidupannya. Dukungan dapat diberikan dalam bentuk apapun baik berupa ucapan maupun suatu pemberian yang nyata. Dukungan diberikan agar seseorang atau suatu kelompok dapat bertahan dalam menjalani berbagai masalah.

Salah satu kelompok yang membutuhkan dukungan adalah kelompok anak tunagrahita. Kelompok ini mendapatkan dukungan khusus dari pihak pemerintah berupa dukungan strategis. Dukungan strategis yang dibentuk oleh pemerintah ini dapat berupa perundangan, peraturan, dan keputusan. Dukungan strategis dapat dibedakan berdasarkan tingkatan, seperti tingkat nasional dan daerah.

Dukungan yang sebenarnya yang sangat dibutuhkan dari kelompok ini adalah dukungan dari keluarga. Peran orang tua dalam perkembangan anak akan menentukan kelangsungan hidup mereka. Orang tua merupakan sekolah pertama yang memberikan pendidikan dasar untuk anak. Selain itu orang tua juga harus dapat memberikan contoh yang baik sebagai pedoman untuk anak-anak.

Terlebih anak dengan kebutuhan khusus atau anak tunagrahita yang cenderung menggantungkan diri kepada orang lain. Orang tualah yang seharusnya selalu ada untuk mendampingi anak-anak seperti ini. Namun pada kenyataannnya, orang tua dengan anak yang memiliki keterbatasan akan merasa terbebani dalam mengasuh anak karena harus mengeluarkan tenaga yang cukup banyak untuk dapat mengasuh anaknya. Sehingga banyak masalah yang muncul dalam merawat anak dengan keterbatasan seperti depresi (Pawiono, Latri and Rosmaharani, 2016).

Dukungan strategis yang dibentuk oleh pemerintah untuk anak tunagrahita meliputi UndangUndang Republik Indonesia Nomor 8 Tahun 2016 tentang penyandang disabilitas, Peraturan Menteri Kesehatan Republik Indonesia Nomor 25 Tahun 2014 tentang Upaya Kesehatan Anak, dan Peraturan Walikota Surabaya Nomor 2 Tahun 2013 tentang Organisasi Unit Pelaksana Teknis Dinas Pondok Sosial Kalijudan pada Dinas Sosial Kota Surabaya.
Anak tunagrahita merupakan salah satu kelompok yang membutuhkan dukungan dalam menjalani kehidupannya. Anak tunagrahita memiliki keterbatasan yang dapat mengganggu atau menghambat kegiatannya secara normal. Pemerintah telah membentuk beberapa kebijakan yang diharapkan dapat membantu kelompok anak tunagrahita ini untuk melangsungkan kehidupannya. Khususnya kelompok anak tunagrahita yang berasal dari keluarga yang tidak mampu (Meria, 2015).

Penyandang disabilitas adalah setiap orang yang mengalami keterbatasan fisik, intelektual, mental, dan/atau sensorik dalam jangka waktu lama yang dalam berinteraksi dengan lingkungan dapat mengalami hambatan dan kesulitan untuk berpartisipasi secara penuh dan efektif dengan warga negara lainnya berdasarkan kesamaan hak (Menkumham, 2016).

Hal tersebut yang menyebabkan kelompok ini menjadi terasing di lingkungannya. Seharusnya setiap manusia memiliki sikap saling menghargai dan menerima keberadaan kelompok ini dengan hak yang sama tanpa kurang satupun. Berdasarakan perundangan ini, penyandang disabilitas berhak mendapatkan 22 hak yang harus dipenuhi. Salah satu hak penting yang harus diterima adalah hak kesehatan.

Kesehatan merupakan kondisi sejahtera badan, jiwa, dan sosial yang memungkinkan seseorang dapat produktif. Dengan kesehatan seseorang akan bisa memperoleh hak-haknya yang lain. Hak kesehatan meliputi hak untuk mendapatkan kehidupan yang sehat, hak mendapatkan pelayanan kesehatan, dan hak mendapatkan perhatian khusus bagi kelompok anak dan ibu. Universal Declaration of Human Right (UDHR) menyatakan bahwa setiap orang berhak atas kehidupan yang layak untuk kesehatan dan kesejahteraan hidupnya. Setiap orang behak atas keamanan saat tidak mempunyai pekerjaan, sakit, acat, lanjut usia, atau keadaan lain yang menyebabkan menurunnya taraf kehidupan seseorang (Lembaga Studi \&Advokasi Masyarakat, 2014).

Hak kesehatan yang harus diterima oleh penyandang disabilitas meliputi hak memperoleh informasi mengenai pelayanan kesehatan, hak memperoleh kesamaan dalam menerima pelayanan kesehatan, hak memperoleh sediaan farmasi sesuai kebutuhan, dan hak memperoleh perlindungan medis.

Penyandang disabilitas wajib mendapatkan fasilitas pelayanan kesehatan yang layak tanpa diskriminasi. Pemerintah menjamin pelayanan kesehatan bagi penyandang disabilitas dalam program Jaminan Kesehatan Nasional (JKN) sesuai ketentuan perundang-undangan. Penyandang disabilitas berhak mendapatkan pelayanan kesehatan sesuai dengan kebutuhan disabilitasnya.

Menurut PMK Nomor 25 Tahun 2014, anak adalah seseorang yang sampai berusia 18 tahun, termasuk anak yang masih dalam kandungan. Sedangkan anak dengan disabilitas adalah anak yang memiliki keterbatasan fisik, mental, intelektual atau sensorik dalam jangka waktu lama, yang dalam berinteraksi dengan lingkungan dan sikap masyarakatnya dapat menemui hambatan yang menyulitkan untuk berpartisipasi penuh dan efektif berdasarkan kesamaan hak. 
Upaya kesehatan anak dilakukan secara terpadu, terintegrasi, dan berkesinambungan dengan tujuan untuk memelihara dan meningkatkan derajat kesehatan anak dengan pencegahan penyakit, pengobatan penyakit, dan pemulihan kesehatan. Dengan kata lain, upaya pemenuhan kesehatan anak dilakukan mulai dari upaya preventif hingga kuratif. Pelayanan kesehatan bagi anak dengan disabilitas dilakukan oleh fasilitas pelayanan kesehatan, sekolah luar biasa, sekolah inklusif, institusi lain, dan keluarga. Pelayanan kesehatan bagi anak dengan disabilitas meliputi penyuluhan tentang kesehatan anak, penyuluhan tentang kesehatan lingkungan, penjaringan kesehatan, pemberantasan sarang nyamuk, imunisasi, pengobatan, konseling dan pelayanan kesehatan jiwa, serta pelayanan kesehatan intelegensia (Menteri Kesehatan Republik Indonesia, 2009).

Selain hak kesehatan yang harus diterima oleh penyandang disabilitas, terdapat hak lain yang harus diterima yaitu hak pendidikan. Kelompok ini sangat memerlukan pendidikan berupa layanan pendidikan khusus yang tidak sama dengan kelompok normal biasanya. Pendidikan khusus ini bertujuan untuk mengoptimalkan kemampuan sesuai dengan potensi yang dimiliki. Contohnya adalah dalam pemecahan masalah, kelompok ini harus berpikir secara optimal. Proses berpikir ini terdiri dari menerima masalah, mengolah informasi dan menemukan penyelesaian masalah (Hidayah, Suhadi and Pangadi, 2014).

Beberapa jenis pendidikan yang dapat diberikan adalah kelas transisi, sekolah khusus (sekolah luar biasa), pendidikan terpadu, program sekolah di rumah, pendidikan inklusif, dan panti (griya) rehabilitasi (Yosiani, 2014).

Untuk memenuhi hak pendidikan, pemerintah harus melakukan beberapa cara salah satunya adalah menyiapkan tenaga guru dengan kompetensi khusus. Guru yang dipekerjakan harus memiliki kualifikasi minimal menguasai bahasa isyarat. Selain itu pemerintah juga harus menyediakan sarana pelatihan untuk melatih para guru di berbagai tingkat pendidikan (Sari, Binahayati and Muhammad, 2017a).

Pemerintah Kota Surabaya membentuk sebuah lembaga sosial yang berada di bawah Dinas Sosial yaitu Unit Pelaksana Teknis Dinas Pondok (UPTD) Sosial Kalijudan(Walikota Surabaya, 2016). UPTD merupakan unsur pelaksana teknis operasional Dinas di lapangan. UPTD melaksanakan tugas di bawah dan bertanggung jawab kepada kepala Dinas (Walikota Surabaya, 2013).

UPTD Ponsos Kalijudan ini dibentuk untuk menampung anak-anak berkebutuhan khusus atau anak tunagrahita yang ada di Surabaya. Untuk melaksanakan tugas UPTD Ponsos Kalijudan ini, Walikota Surabaya membuat Peraturan Walikota Surabaya Nomor 2 Tahun 2013 Tentang Organisasi Unit Pelaksana Teknis Dinas Pondok Sosial Kalijudan pada Dinas Sosial Kota Surabaya.

UPTD Ponsos Kalijudan ini memiliki tugas untuk memenuhi kebutuhan anak-anak tunagrahita yang ditampung disana. Pemenuhan kebutuhan tersebut meliputi pemenuhan kebutuhan jasmani, pemenuhan kebutuhan spiritual, dan pemenuhan pelayanan kesehatan.
Berdasarkan kebijakan yang ada, dukungan strategis pemerintah terhadap kelompok anak tunagrahita sudah cukup baik khususnya di Kota Surabaya. Dengan adanya UPTD Pondok Sosial Kalijudan, anak tunagrahita yang terlantar dapat dirawat dengan layak. Namun masih terdapat beberapa hal yang seharusnya dimuat dalam kebijakan. Dalam Undang-Undang Republik Indonesia Nomor 8 Tahun 2016 kurang dijelaskan klasifikasi penyandang disabilitas secara spesifik. Hal ini tentunya membuat rancu bagi kalangan masyarakat untuk membedakan anak tunagrahita dengan kelompok lainnya.

Dalam Peraturan Menteri Kesehatan Nomor 25 Tahun 2014 telah disebutkan beberapa upaya kesehatan yang harus diterima oleh anak tunagrahita. Maka diharapkan PMK ini dapat digunakan sebagai pedoman untuk menyelenggarakan upaya kesehatan di lembaga-lembaga sosial yang menampung anak tunagrahita.

\section{Dukungan Operasional}

Selain dukungan strategis dalam bentuk perundangan dan peraturan-peraturan, pemenuhan hak kesehatan anak tunagrahita juga didukung secara operasional. Sebagai contoh dukungan operasional pemenuhan hak kesehatan anak tunagrahita telah dilaksakan oleh Unit Pelaksana Teknis Dinas (UPTD) Pondok Sosial Kalijudan Kota Surabaya. UPTD Ponsos Kalijudan sebagai lembaga kesejahteraan sosial yang menampung anak-anak berkebutuhan khusus atau anak tunagrahita wajib memberikan pelayanan penuh berupa pemenuhan kebutuhan anak tunagrahita. Pemenuhan kebutuhan tersebut terdiri dari pemenuhan kebutuhan jasmani/dasar, pemenuhan kebutuhan spiritual, dan pemenuhan pelayanan kesehatan.

Pemenuhan kebutuhan jasmani/dasar yang diberikan kepada anak tunagrahita berupa pemenuhan kebutuhan sandang, pangan, dan papan. Anak-anak tunagrahita mendapatkan pakaian yang layak. Mereka juga mendapatkan makan sebanyak tiga kali sehari. Tidak jarang juga mereka mendapatkan makanan ringan dari kegiatan bakti sosial. Pemenuhan kebutuhan papan yang diberikan berupa asrama beserta fasilitasnya seperti kamar tidur, kamar mandi, tempat bermain, dan lain-lain.

Pemenuhan kebutuhan spiritual yang diberikan kepada anak tunagrahita dilakukan dengan pembelajaran. Pembelajaran ini diarahkan pada upaya membangun kejiwaan, kepercayaan diri, dan tingkah laku yang tidak tepat. Pembelajaran agama pada anak tunagrahita tentu berbeda sehingga dibutuhkan penyampaian yang lebih efektif (Meria, 2015).

Pemenuhan kebutuhan spiritual yang diberikan adalah dalam bentuk bimbingan yang disampaikan oleh pengasuh asrama. Bimbingan yang diberikan tidak banyak karena tenaga pembimbing disana tidak memenuhi kualifikasi tertentu. Bimbingan yang diberikan meliputi bimbingan praktek berwudhu, bimbingan praktek sholat, hafalan surat pendek, dan hafalan doa sehari-hari. Walaupun tidak banyak yang diajarkan kepada mereka namun minimal mereka mengetahui pentingnya mengenal tuhannya dan melaksanaka kewajiban. 
Berdasarkan Undang-Undang Republik Indonesia Nomor 8 Tahun 2016 Tentang Penyandang Disabilitas, penyandang disabilitas memilki beberapa hak yang harus dipenuhi sama seperti manusia normal. Salah satu hak yang harus dipenuhi adalah hak kesehatan. Hak kesehatan yang harus diterima meliputi hak memperoleh informasi tentang pelayanan kesehatan, hak memperoleh kesamaan di bidang kesehatan, hak memperoleh perbekalan farmasi dan alat bantu kesehatan yang layak, dan hak untuk mendapatkan perlindungan medis.

Pemerintah Kota Surabaya melalui UPTD Ponsos Kalijudan berupaya untuk memenuhi hak kesehatan anak-anak tunagrahita yang ada di Kota Surabaya dengan kondisi keluarga yang tidak memungkinkan untuk mengasuhnya. UPTD Ponsos Kalijudan menampung 50 anak dengan kebutuhan khusus atau anak tunagrahita dari hasil penjaringan baik itu dari hasil razia Satpol PP, disposisi Ibu Wali Kota, dan laporan dari pihak kelurahan atau kecamatan. Untuk memenuhi kebutuhan pelayanan kesehatan, UPTD Ponsos Kalijudan bekerja sama dengan beberapa pihak yang terkait seperti Puskesmas, Rumah Sakit, dan Dinas Kesehatan.

Berdasarkan Peraturan Menteri Kesehatan Republik Indonesia Nomor 25 Tahun 2014 Tentang Upaya Kesehatan Anak, pelayanan kesehatan bagi anak dengan disabilitas yang harus dipenuhi oleh puskesmas meliputi penyuluhan tentang kesehatan anak, penyuluhan tentang kesehatan lingkungan, penjaringan kesehatan, pemberantasan sarang nyamuk, imunisasi, pengobatan, konseling dan pelayanan kesehatan jiwa, serta pelayanan kesehatan intelegensia.

Tabel 1. Pelaksaan Pemenuhan Pelayanan Kesehatan untuk Anak Tunagrahita di UPTD Ponsos Kalijudan Surabaya

\begin{tabular}{|c|c|c|c|}
\hline \multirow[b]{2}{*}{ Pelayanan Kesehatan } & \multicolumn{2}{|c|}{ Realisasi } & \multirow{2}{*}{$\begin{array}{c}\text { Pihak yang Terlibat dalam } \\
\text { Pelaksanaan }\end{array}$} \\
\hline & Terlaksana & $\begin{array}{c}\text { Tidak } \\
\text { Terlaksana }\end{array}$ & \\
\hline Penyuluhan tentang kesehatan anak & - & $\sqrt{ }$ & - \\
\hline Penyuluhan tentang kesehatan lingkungan & - & $\sqrt{ }$ & - \\
\hline Penjaringan kesehatan & - & $\sqrt{ }$ & - \\
\hline Pemberantasan sarang nyamuk & - & $\sqrt{ }$ & - \\
\hline Imunisasi & $\sqrt{ }$ & - & Puskesmas \\
\hline Pengobatan & $\sqrt{ }$ & - & Puskesmas dan rumah sakit \\
\hline Konseling dan pelayanan kesehatan jiwa & $\sqrt{ }$ & - & Rumah sakit jiwa \\
\hline Pelayanan kesehatan intelegensia & - & $\sqrt{ }$ & - \\
\hline
\end{tabular}

Pelaksanaan pemenuhan pelayanan kesehatan untuk anak tunagrahita di UPTD Ponsos Kalijudan pada tabel 1. Berdasarkan tabel 1, dari delapan pelayanan kesehatan yang harus diberikan kepada anak tunagrahita, hanya tiga pelayanan kesehatan yang diberikan. Pelayanan kesehatan menurut PMK Nomor 25 Tahun 2014 yang telah diberikan yaitu imunisasi, pengobatan, dan konseling dan pelayanan kesehatan jiwa. Pelayanan ini diberikan dengan bekerja sama dengan pihak-pihak yang terkait seperti puskesmas, rumah sakit umum, dan rumah sakit jiwa.

Berdasarkan hasil wawancara dengan Kasubag Tata Usaha UPTD Ponsos Kalijudan, pelayanan kesehatan minimal berdasarkan PMK Nomor 25 Tahun 2014 tidak terlaksana sepenuhnya. Hal ini disebabkan karena kondisi anak tunagrahita yang dirawat di UPTD Ponsos Kalijudan berbeda-beda. Sehingga pelayanan kesehatan hanya diberikan sesuai dengan kebutuhan setiap anak.

Seperti pelayanan kesehatan penyuluhan, pelayanan kesehatan ini dinilai tidak efektif diberikan kepada anak-anak tunagrahita disana karena mereka memiliki kemapuan intelektual yang rendah untuk memahami sebuah penyuluhan. Sehingga upaya yang dilakukan oleh pihak UPTD Ponsos Kalijudan adalah dengan memberikan komunikasi informasi yang edukatif yang langsung dapat dipraktekkan oleh anak-anak tunagrahita. KIE ini disesuaikan dengan kegiatan mereka sehari-hari seperti menggosok gigi dan mencuci tangan sebelum makan. Walaupun sangat sederhana setidaknya anak-anak mengetahui upaya-upaya prevetif untuk menjaga kesehatan mereka.

Penjaringan kesehatan merupakan pelayanan kesehatan barupa skrining kesehatan. Skrining kesehatan ini dilakukan untuk mengetahui lebih dini masalah kesehatan yang diderita oleh seseorang sehingga dapat dilakukan pencegahan agar masalah kesehatan tersebut dapat diminimalisir. Penjaringan kesehatan ini seharusnya dilakukan pada tahap penerimaan saat anak tunagrahita akan dititipkan di UPTD Ponsos Kalijudan. Namun dalam pelaksanaannya tidak ada kegiatan penjaringan kesehatan yang dikakukan. Menurut pengasuh asrama, seharusnya ada petugas kesehatan yang berjaga di UPTD Ponsos Kalijudan untuk memberikan pelayanan apabila sewaktu-waktu terdapat anak yang mengalami masalah kesehatan.

Pelayanan kesehatan yang telah diberikan untuk anak tunagrahita adalah imunisasi, pengobatan, dan konseling dan pelayanan kesehatan jiwa. Imunisasi yang diberikan merupakan imunisasi ORI (Outbreak Response Imunization). Pada tahun 2018 ini telah diberikan ORI difteri untuk anak-anak tunagrahita di UPTD Ponsos Kalijudan yang bekerja sama dengan Puskemas terdekat. Selain imunisasi, anak-anak 
tunagrahita juga diberikan pelayanan kesehatan pengobatan. Pelayanan ini diberikan pada saat anak tunagrahita mengalami gangguan kesehatan. Mereka akan dibawa ke puskesmas untuk mendapatkan pengobatan. Apabila puskesmas tidak dapat menangani maka dapat dirujuk ke rumah sakit yang telah ditentukan dengan prosedur tertentu.

Konseling dan pelayanan kesehatan jiwa juga diberikan kepada anak-anak yang terindikasi mengalami gangguan jiwa. Anak tunagrahita memang terlihat seperti mengalami gangguan jiwa, hal tersebut dikarenakan mereka memiliki tingkat intelektual yang rendah sehingga terlihat seperti gangguan jiwa. Apabila terdapat anak tunagrahita yang diindikasikan mengalami gangguan jiwa, maka anak tersebut akan dibawa ke rumah sakit jiwa untuk mendapatkan perawatan.

Selain berdasarkan peraturan yang berlaku, UPTD Ponsos Kalijudan telah melakukan pelayanan kesehatan yang bekerja sama dengan pihak terkait seperti puskesmas dan dinak kesehatan. Setiap bulan, puskesmas melakukan pemeriksaan rutin kepada anak-anak tunagrahita. Pemeriksaan yang dilakukan adalah pengecekan kesehatan dasar seperti mengukur berat badan, mengukur tinggi badan, dan mengukur tekanan darah. Dinas Kesehatan Kota Surabaya memiliki rumah ABK yang memberikan pelayanan berupa pelatihan berbicara dan mendengar bagi penyandang tuna runguwicara.

Upaya-upaya ini sudah cukup baik untuk memenuhi kebutuhan hak kesehatan bagi anakanak tunagrahita yang diasuh di UPTD Ponsos Kalijudan. Pemerintah Kota Surabaya sudah berusaha semaksimal mungkin untuk memberikan penghidupan yang layak bagi anak-anak tunagrahita yang tidak mampu dengan adanya UPTD Ponsos Kalijudan ini.

\section{SIMPULAN}

Berdasakan hasil telaah kebijakan dan observasi yang diperoleh, maka dapat disimpulkan bahwa dukungan strategis pemerintah untuk mendukung anak tunagrahita adalah UndangUndang Republik Indonesia Nomor 8 Tahun 2016 tentang penyandang disabilitas, Peraturan Menteri Kesehatan Republik Indonesia Nomor 25 Tahun 2014 tentang upaya kesehatan anak, dan Peraturan Walikota Surabaya Nomor 2 Tahun 2013 tentang Organisasi Pondok Sosial Kalijudan pada Dinas Sosial Kota Surabaya. Sedangkan, dukungan operasional yang dilakukan UPTD Ponsos Kalijudan untuk memenuhi hak kesehatan anak tunagrahita adalah dengan melakukan kerjasama dengan pihak terkait. Pelayanan kesehatan yang diterima oleh anak tunagrahita yaitu pemeriksaan rutin dari puskesmas terdekat dan kunjungan ke rumah $A B K$ bagi penyandang tuna runguwicara.

\section{DAFTAR PUSTAKA}

Awalia, H. R. (2016) 'Studi Deskriptif Kemampuan Interaksi Sosial Anak Tunagrahita Ringan', Jurnal Pendidikan Luar Biasa, 9(1), pp. 116. Available at: http://jurnalmahasiswa.unesa.ac.id/index.php /jurnal-pendidikan-

khusus/article/view/17924/16332.

Badan Pusat Statistik Provinsi Jawa Timur (2017) Penyandang Masalah Kesejahteraan Sosial Menurut Kabupaten/Kota 2016, Badan Pusat Statistik Provinsi Jawa Timur. Available at: https://jatim.bps.go.id/statictable/2017/10/10/ 650/penyandang-masalah-kesejahteraansosial-menurut-kabupaten-kota-2016.html (Accessed: 12 January 2018).

Hidayah, M., Suhadi, I. and Pangadi (2014) 'Proses Berpikir Siswa Tunagrahita Ringan dalam Memecahkan Masalah Matematika Bentuk Soal Cerita pada Operasi Hitung Campuran', Journal of Mathematics and Mathematics Education, 4(1), pp. 20-32. Available at: http://jurnal.fkip.uns.ac.id/index.php/jmme/art icle/view/10032.

Kementerian Hukum dan Hak Asasi Manusia Republik Indonesia (2016) Undang-Undang Republik Indonesia Nomor 8 Tahun 2016 tentang Penyandang Disabilitas. Indonesia.

Kementerian Kesehatan Republik Indonesia (2009) Anak dengan Tunagrahita Perlu Pendekatan Khusus, Kementerian Kesehatan Republik Indonesia. Available at: http://www.depkes.go.id/pdf.php?id=460 (Accessed: 10 January 2018).

Kementerian Kesehatan Republik Indonesia (2014) Peraturan Menteri Kesehatan Republik Indonesia Nomor 25 Tahun 2014 tentang Upaya Kesehatan Anak, Peraturan Menteri Kesehatan Republik Indonesia Nomor 25 Tahun 2014. Indonesia.

Lembaga Studi \&Advokasi Masyarakat (2014) Kesehatan Sebagai Hak Asasi Manusia, Koleksi Pusat Dokumentasi ELSAM. Available at: http://referensi.elsam.or.id/wpcontent/uploads/2014/12/KESEHATANSEBAGAI-HAK-ASASI-MANUSIA.pdf (Accessed: 11 January 2018).

Meria, A. (2015) 'Model Pembelajaran Agama Islam bagi Anak Tunagrahita di SDLB YPPLB Padang Sumatera Barat', Jurnal Tsafaqah, 11(2), pp. 355-380. Available at: https://www.researchgate.net/publication/304 432383_Model_Pembelajaran_Agama_Islam bagi Anak Tunagrahita di SDLBYPPLB Padang_Sumatra_Barat.

Pawiono, Latri, R. K. and Rosmaharani, S. (2017) 'Hubungan Dukungan Keluarga Dengan Tingkat Depresi Keluarga dalam Merawat Anak Retardasi Mental (The Correlation Family Support With The Level Of Family Depression For Caring Mental Retardation Children)', Jurnal IImiah Keperawatan, 3(1), pp. 85-91. Available at: https://jurnalperawat.stikespemkabjombang. ac.id/index.php/maret2017/article/download/ $44 / 41$.

Presiden Republik Indonesia (1991) Peraturan Pemerintah Republik Indonesia Nomor 72 Tahun 1991 tentang Pendidikan Luar Biasa. Indonesia.

Putri, D. F. I. (2015) 'Peran Unit Pelaksana Teknis Dinas (UPTD) Pondok Sosial Kalijudan Kota 
Surabaya dalam Pembinaan Anak Penyandang Tunagrahita', Jurnal Publiika, 3(5), pp. 1-15. Available at: http://jurnalmahasiswa.unesa.ac.id/index.php /publika/article/view/11915/11118.

Sari, S. F. M., Binahayati and Muhammad, B. (2017) 'Pendidikan Bagi Anak Tunagrahita (Studi Kasus Tunagrahita Sedang di SLB N Purwakarta)', Jurnal Penelitian \& PKM, 4(2), pp. 129-389.

Shabrina, R. (2017) 13 Cara Menangani Anak Berkebutuhan Khusus, Dosen Psikologi. Available

at: https://dosenpsikologi.com/cara-menanganianak-berkebutuhan-khusus (Accessed: 11 January 2018).

Ulfatusholiat, R. (2012) Peran Orangtua dalam Penyesuaian Diri Anak Tunagrahita. Depok. Available at: http://publication.gunadarma.ac.id/handle/12 $3456789 / 1949$.

Walikota Surabaya (2013) Peraturan Walikota Surabaya Nomor 2 Tahun 2013 tentang Organisasi Unit Pelaksana Teknis Dinas Pondok Sosial Kalijudan pada Dinas Sosial Kota Surabaya. Indonesia.

Walikota Surabaya (2016) Keputusan Walikota Surabaya Nomor: 188.45/34/436.1.2/2017 tentang Tim Pelayanan Keluhan/Pengaduan Masyarakat Kota Surabaya. Indonesia.

Yosiani, N. (2014) 'Relasi Karakteristik Anak Tunagrahita dengan Pola Tata Ruang Belajar di Sekolah Luar Biasa', E-Journal Graduate Unpar, 1(2), pp. 111-124. 